\author{
Владимир Ајзенхамер
}

\title{
Никсон, Кисинџер и Мао: Од стратешке триангулације до Пинг-понг дипломатије
}

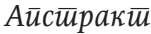

Рад је замишљен као екскурс на тему америчко-кинеских односа, чији је задатак да читаоцу приближи сложену историјску позадину дипломатске иницијативе која је у историји хладноратовске политике остала упамћена под називом Пинг-понг дипломатија. У питању је један од најпознатијих и свакако најчешће навођених примера коришћења тзв. спортске дипломатије у сврху стварања прилике за отпочињање или одмрзавање билатералних односа између две државе - Сједињених Америчких Држава и Народне Републике Кине - држава чија је међусобна перцепција, услед драстичних идеолошких разлика и супротстављених геополитичких интереса, била оптерећена наизглед непремостивим узајамним неповерењем. У раду ће, на примеру америчко-кинеског rapprochement-a, бити апострофиран пресудан утицај политичког вођства на осмишљавање и реализацију спољнополитичке стратегије. Такође, на овом примеру ћемо показати како флексибилно позиционирање агенса према структури може, дугорочно гледано, довести до промена саме структуре. Као фактор који је пресудно утицао на нормализацију односа између САД и НР Кине аутор рада акцентује међусобно подударање стратешке процене политичког двојца Никсон-Кисинџер, са једне, и кинеског лидера Мао Цедунга, са друге стране.

Први део рада биће посвећен дескрипцији међународних околности које су претходиле америчко-кинеском зближавању, да би потом фокус био усмерен ка стратегији триангулације билатералних односа између САД и СССР-а, САД и НР Кине и НР Кине и СССР-а.
\end{abstract}

Кљуине речи:

америчко-кинески односи, Ричард Никсон, Хенри Кисинџер, Мао Цедунг, хладни рат, стратегија, триангулација, САД, НР Кина, СССР 


\section{УВОД}

Тридесет прво Светско првенству у стоном тенису, одржано на пролеће 1971. у јапанском граду Нагоји, остало је упамћено по случајном сусрету чланова америчке и кинеске спортске репрезентације чије су политичке импликације многоструко превазишле обичан дух спортске солидарности и џентлменства који је негован на таквим манифестацијама. До сусрета је дошло када је америчког репрезентативца Глена Кована (Glenn Cowan), који је закаснио на аутобус у коме се налазио његов тим, од хотела на турнир, повезла кинеска репрезентација. Током вожње, Ковану се пружила прилика да разговара са кинеским светским шампионом Зуангом Зедонгом (Zhuang Zedong) и да са њиме успостави срдачан однос који је, већ следећег дана, резултирао још једним сусретом два стонотенисера. Двојица спортиста су том приликом разменила дарове, а кинеска страна иницирала је позив за одржавање заједничког стонотениског меча. Остало је историја - сусрет је потом искоришћен, како од стране Пекинга тако и од стране Вашингтона, као подстицај за даље успостављање званичног дијалога на највишем нивоу, што је напослетку довело до чувене Никсонове (Richard Nixon) посете Народној Републици Кини (у даљем тексту НР Кина) 1972. године и потписивања Шангајског коминикеа.

Кратка хронологија догађаја који су претходили сусрету у Нагоји изгледа овако. Од 1958. године НР Кина се, услед спора са Републиком Кином (у наставку текста Тајван), повукла из већине светских спортских савеза. Званични став Пекинга гласио је да НР Кина не може бити чланица ниједне спортске организације у чијем чланству се налази Тајван, чиме је себи наметнула спортску самоизолацију суздржавајући се од учешћа на свим значајнијим светским спортским дешавањима. Пекинг је као својеврсну излазну карту задржао чланство у Светској стонотениској федерацији (Kobierecki, 2016, р. 308). Ипак, и у оквиру ње, Кина је наступ прилагођавала политици непризнавања Тајвана. Из тог разлога кинеска репрезентација није учествовала на претходна два турнира одржана у Стокхолму и Минхену. Међутим, са значајном променом спољнополитичких околности, до којих је дошло услед интензивирања процеса антагонизације односа између НР Кине и Совјетског Савеза (у даљем тексту СССР), о чему ће више речи бити у наставку рада, Пекинг је био вољан да заузме флексибилнију позицију и да учешћем на предстојећем светском првенству покаже спремност на политичко отварање према свету. Иза спортских кулиса ова одлука је заправо била одговор на позитивне политичке сигнале који су у Пекинг, током претходне две године, стизали из Вашингтона. Важно је напоменути да тежња 
ка rapprochement-у нипошто није била јединствен став нити кинеског руководства нити администрације Ричарда Никсона, која је 1968. године преузела дужност у Овалном кабинету. У Кини зближавању су нагињали Мао Цедунг (Maо Zedong) и премијер Џоу Енлај (Zhou Enlai), док су његови заговорници са америчке стране били председник Никсон и његов саветник за националну безбедност Хенри Кисинџер (Henry Kissinger). Код куће, Мао и Енлај су се суочавали са неповерљивошћу бирократских кругова унутар Министарства спољних послова и Државне комисије за спорт и физичку културу, који су се противили сваком потенцијалном уступку везаном за Тајван. С друге стране, Кисинџер и Никсон су на домаћем терену водили борбу са опозицијом унутар Стејт департмента и Савета за националну безбедност, где је преовладавала бојазан да би зближавање са Кином угрозило већ ионако крхке односе са СССР-ом.

Упркос противљењу делова политичког естаблишмента, лидери обе земље успели су да наметну своју визију и да низом опрезних али узајамно охрабрујућих дипломатских потеза и политичких уступака створе простор за унапређење билатералних односа. Пинг-понг дипломатија била је врхунац овог дипломатског плеса који је „за само неколико дана значајно променио политичку климу која се тицала сино-америчких односа" (Kobierecki, 2016, p. 311). Дугорочно гледано, овај „фини манует”, како је Кисинџер у својим мемоарима описао процес постепеног измирења две државе (Кисинџер, 1981, стр. 201), отворио је пут ка драстичној рекомпозицији ширег геополитичког пејзажа и довео до стратешке триангулације односа унутар кључног хладноратовског троугла - Cједињене Америчке Државе (у даљем тексту САД,) СССР и НР Кина, чиме је у потпуности измењен даљи ток Хладног рата.

У наставку рада позабавићемо се међународним околностима које су довеле до америчко-кинеског приближавања, да бисмо се потом фокусирали на улогу коју су Никсон (заједно са Кисинџером) и Мао имали у иницирању и реализацији зближавања две државе. ${ }^{1}$ Акценат ће, са

1 Улога политичког лидерства у вођењу светске политике, нарочито када је у питању осмишљавање и вођење спољне политике, један је од аналитичких нивоа у оквиру спољнополитичке анализе (Foreign Policy Analysis) као поддисциплине науке о међународним односима (Hudson 2005, pp. 2, 10-11, 17-18; Jackson, Sorensen, 2013, pp. 263-266). Такође, унутар саме дисциплине одређени теоријски приступи и њихови „огранци” за кључан фактор у међународним односима узимају актера - првенствено државе и њихова политичка руководства, али и друге елементе innenpolitk-e (унутрашње политике) који утичу на процес спољнополитичког одлучивања. У том контексту посебно се издвајају поједини правци реалистичке теорије - класични и неокласични реализам (Morgentau, 1959; Rose, 1998; Taliaferro, 2000). Ми се у раду нећемо бавити провером њихових полазних претпоставки, већ 
једне стране, бити стављен на мотиве, циљеве и импликације стратешке триангулације коју су заједно осмислили Никсон и Кисинџер. Са друге, у центру пажње наћи ће се разлози који су навели Маоа да прекине кинеску самоизолацију и да за стратешки спољнополитички императив прихвати нормализацију а потом и унапређење односа са САД. У закључном делу рада апострофираћемо значај индивидуалне лидерске процене међународних околности и указати на то да вешто позиционирање агенса према структури може, дугорочно гледано, довести и до значајних промена саме структуре.

\section{ХЛАДНОРАТОВСКЕ ГЕОСТРАТЕШКЕ ПОЗИЦИЈЕ САД И НР КИНЕ}

Након коначне победе кинеских комуниста у грађанском рату против Куомитанга (Kuomintang), САД су одбиле да признају новопроглашену Народну Републику Кину и своју подршку су фокусирале на Тајван, на коме је националистичка влада предвођена Чаном Кај-Шеком (Chiang Kai-shek) формирала Републику Кину. Тако је у првим годинама Хладнога рата створена парадоксална ситуација у којој је влада Тајвана преузела легални и од стране Запада признати државни континуитет са некадашњом кинеском републиком успостављеном 1912, док је комунистичка Кина, која је обухватила читаво копно и највећи део становништва остала непризната од стране шире међународне заједнице. Тајван је од стране западног блока добио признање државног континуитета и место у Уједињеним нацијама, док се НР Кина повукла у релативну самоизолацију, успостављајући блиске односе искључиво са државама комунистичке провенијенције.

Ситуација је драстично промењена када је 1956. дошло до раскола између комунистичких власти у Москви и Пекингу, након што су се кинески комунисти успротивили критичком и ревизионистичком ставу Никите Хрушчова (Nikita Khrushchev) према Стаљиновом (Joseph Stalin) политичком и идеолошком легату (Kobierecki, 2016, p. 305). Међусобно неповерење додатно је продубљено две године касније кад је кинеско руководство започело реформску кампању познату под називом „Велики скок напред”, чиме је направљен отклон од совјетског друштвено-економског социјалистичког модела. Измештање револуционарног фокуса са пролетеријата на сељаштво, које је заговарао Мао,

их узимамо као полазну тачку којом оправдавамо опредељење за индивидуални ниво спољнополитичке анализе. 
у Москви је протумачено као идеолошка јерес. Овај раскол Кисинџер је описао на следећи начин: „У односима Москве и Пекинга избила су идеолошка неслагања због тврдње Кинеза да су ушли у комунизам прескочивши фазу социјализма. Била је то доктрина Мао Це Тунга која је, заправо, имплицирала да је Пекинг идеолошки чистији од Москве. Исто тако се осећао ривалитет двеју моћних држава, а повећавало се и међусобно неповерење" (Кисинџер, 1981, стр. 178). У годинама које су уследиле билатерални односи некадашњих савезника бивали су све лошији. Москва је обуставила сваку економску помоћ Пекингу, повукла је своје техничке саветнике из Кине, а Хрушчов је одбио да са Кином сарађује на нуклеарном плану.

Током шездесетих година ситуација се погоршала до нивоа отвореног политичког конфликта, а тзв. „Брежњевљева доктрина” (Leonid Brezhnev) довела је два комунистичка гиганта на корак до ратне ескалације. Ова спољнополитичка доктрина, која би се најједноставније могла окарактерисати као самопроглашење Москве за арбитра светске револуције, предвиђала је могућност совјетске војне интервенције у оним социјалистичким државама које „изневере” комунистички (читај - совјетски) развојни модел и почну да кокетирају са капитализмом. Она је послужила као идеолошко покриће за совјетску војну инвазију на Чехословачку и гушење Прашког пролећа 1968. године. Поменути догађаји изазвали су велику нервозу у Пекингу и зебњу да ће управо кинеско комунистичко руководство и сама НР Кина бити наредна мета совјетског интервенционизма. Стога је став Пекинга на догађаје у Чехословачкој био знатно оштрији него његове реакције на пређашње кризе унутар комунистичког блока. За време политичких немира у Пољској и Мађарској 1956. кинеско руководство је покушало да делује као медијатор и помиритељ, међутим, овога пута Кинези су „одговорили погрдном осудом Совјетског Савеза" (Кисинџер, 1981, стр. 178). Брежњевљеву доктрину ограниченог суверенитета дневник Комунистичке партије Кине Женмин жибао (Renmín Rìbao) је „осудио као 'крајње фашистичку теорију', сматрајући да би се стварно значење те доктрине могло применити и на Кину као и на било коју источноевропску земљу" (Кисинџер, 1981, стр. 178). Војну инвазију на Чехословачку поменути лист назвао је „'оружаном агресијом и војном окупацијом' коју је повела совјетска ревизионистичка клика" (Кисинџер, 1981, стр. 178). Овако оштар дискурс јасно је указао на то да Пекинг не планира да одступи од своје идеолошке „правоверности” и да је кренуо у мобилизацију свих унутрашњих снага потребних за пружање отпора евентуалној војној агресији од стране совјетских „ревизиониста”. 
Даљи развој догађаја потврдио је да забринутост кинеског руководства није била безразложна. Све чешћи гранични инциденти довели су до гомилања војних снага са обе стране совјетско-кинеске границе. Кинеске зебње додатно је поспешила и чињеница да су Совјети у пограничним областима инсталирали ракете земља-земља опремљене нуклеарним бојевим главама. Потписивање „Уговора о пријатељству, сарадњи и међусобној помоћи" између СССР-а и Монголије 1966, према коме је Совјетски Савез на „територији Монголије могао држати трупе и успостављати војне базе" (Кисинџер, 1981, стр. 179), појачало је уверење Пекинга да се око НР Кине затвара совјетски обруч и да се претња ратног сукоба сваким даном све више увећава.

Тензије су ескалирале војним сукобима на пограничном острву Дамаски/Чепао, на реци Усури 1969. године. Повод је био неслагање око демаркационе линије, а до размене ватре је дошло када је совјетска патрола упала у заседу коју су јој поставиле знатно бројније кинеске снаге. Совјети су приликом овог кратког сукоба претрпели и људске губитке двадесет троје мртвих и четрнаест рањених граничара (Кисинџер, 1981, стр. 184), али су већ током наредног окршаја, који се одиграо две недеље касније, у сукоб ушли знатно спремнији. Борбе су том приликом трајале пуних девет сати а употребљена је и артиљерија и војна механизација. Сукоби су убрзо потом пренети и на друге делове совјетско-кинеске границе, тј. у пограничне пределе између Казахстана и Синкјанга. Совјетски министар одбране Андреј Гречко (Andrei Grechko) је тим поводом сврстао „Кину, заједно са Сједињеним Државама и Западном Немачком, међу главне совјетске непријатеље" (Кисинџер, 1981, стр. 190). Недуго потом кинеска агенција Синхуа (Xinhua) је „оптужила СССР да се припрема за рат и саветовала кинеском народу да учини исто" (Кисинџер, 1981, стр.196). Борбена реторика се све више заоштравала на обе стране а рат се чинио све извеснијим.

На другој страни идеолошко-блоковског спектра САД су се такође суочавале са озбиљним међународним изазовима. Хладни рат је ушао у своју зрелу фазу, избрисавши почетну предност коју је САД имала када је у питању нуклеарни арсенал. Како то примећују Кегли (Charles Kegley) и Виткоф (Eugene Wittkopf): „Све већа опасност од узајамног уништења, заједно са све приближнијом војном снагом САД и СССР, учинила је да коегзистенција или пропаст постане једина алтернатива. Имајући у виду ову једначину, проналажење начина за коегзистенцију постало је императив" (Кегли, Виткоф, 2004, стр. 199). Након Никсоновог уласка у Белу кућу, нова америчка администрација опредељује се за проактивну политику нормализације односа са СССР-ом, која ће 1969. године и званично бити прозвана „детантом” (Кисинџер, 2011, стр. 643). 
Овај спољнополитички заокрет наишао је на повољан одзив Москве, те је детант убрзо прихваћен и као званична политика СССР-а према Вашингтону. Питање побољшања међусобних односа било је уско испреплетено са питањима међународне безбедности а „контрола наоружања била је у средишту разговора који су се водили о детанту. Разговори о ограничењу стратешког наоружања (SALT), иницирани 1969. године, настојали су да ограниче претећу, експанзивну и све бржу трку у наоружању ограничавањем постављања антибалистичких пројектила" (Кегли, Виткоф, 2004, стр. 200). Међутим, узајамно отварање два хладноратовска ривала одвијало се постепено, и налазило се под сталним знаком питања, услед чега је Никсон трагао за адекватним стратешким маневром који би задржао Москву за преговарачким столом и осигурао извесност детанта.

Поред потраге за рецептом за успешну реализацију детанта, Никсонова администрација је такође тражила начин да се ослободи наслеђеног баласта Вијетнамског рата. Рат у Вијетнаму се отегао и постао је прескуп за САД у сваком погледу: „Америчка умешаност ескалирала је средином 1960-их, али је рат постајао све непопуларнији код куће услед пораста броја жртава и замагљеног и неуверљивог образложења америчког ангажмана" (Wittkopf, Kegley, 2003, p. 51). Вијетнамски гордијев чвор ставио је Никсонову администрацију, већ на почетку њеног првог мандата, пред императив потраге за алтернативним спољнополитичким успехом који би привремено скренуо пажњу америчке и светске јавности са дешавања у Индокини. Како је детант са СССР-ом још увек био work in progress са неизвесним исходом, Никсон и Кисинџер су на проналажење заједничког језика са кинеским комунистичким руководством и успостављање билатералних односа са НР Кином гледали као на покушај превазилажења незавидне политичке ситуације, како код куће тако и на међународном плану. Био је то, у неку руку, хазардерски избор јер је заокрет ка Кини са собом носио ризик одвраћања СССР од преговарачког стола, док је на унутрашњем плану претио да изазове незадовољство и отпор оних елемената у америчком бирократском апарату који су, из различитих побуда, заговарали крајњу непопустљивост ка Кини. 


\section{„НИКСИНЏЕРОВА” ГЕОПОЛИТИЧКА ТРИАНГУЛАЦИЈА И МАОВ СТРАТЕШКИ ИМПЕРАТИВ}

Иако је Ричард Никсон и мимо Хенрија Кисинџера био чврст заговорник америчко-кинеског приближавања, прекидања кинеске (само)изолације и инклузије Пекинга у међународну заједницу, његов саветник за националну безбедност је тај који је заслужан за спровођење ових идеја у дело. Притом, на уму треба имати да је једно од главних обележја Никсонове политике било настојање да централизује вођење америчке спољне политике, и да ланац доношења спољнополитичких одлука скрати на што мањи број карика. Како то примећује Кен Хјуз (Ken Hughes), Никсон je „држао свог државног секретара Вилијама Роџерса (William Rogers) и свог секретара одбране Мелвина Ларида (Melvin Laird) неупућене у кључна питања спољне политике. Његов главни инструмент контроле над оним што је он називао 'бирократијом' био је његов саветник за питања националне безбедности, Хенри Кисинџер. Њих двојица су сарађивали толико блиско, да се на њих понекада реферише надимком 'Никсинџер'. Заједно, они су користили Савет за националну безбедност да концентришу моћ у Белој кући - тј. слободно можемо рећи, „у рукама њих двојице" (Hughes, 2021).

У својим „Мемоарима” Кисинџер напомиње како су он и Никсон, независно један од другог, дошли до истоветних закључака о неопходности промене америчке политике према НР Кини (Кисинџер, 1981, стр. 175). Још пре уласка у Белу кућу Никсон је у тексту написаном за часопис Foreign Affairs 1967. године на следећи начин сажео своја размишљања о овом питању: „Гледајући дугорочно, ми једноставно не можемо приуштити да Кину оставимо заувек изван породице нација, да тамо негује своје фантазије, гаји мржњу и прети својим суседима. Нема места на овако малој планети за милијарду потенцијално најспособнијих људи, да живе у бесној изолацији [...] Свет не може бити сигуран док се Кина не промени. Стога би наш циљ, у мери у којој можемо утицати на догађаје, требао бити подстицање те промене. Начин да се то постигне је да се Кина убеди да је промена нужна: да је задовољење њених империјалних амбиција неизводљиво и да је у њеном националном интересу да се окрене од авантура у иностранству ка решавању сопствених унутрашњих проблема" (Nixon, 1967, р. 121). Овим текстом Никсон је зацртао основни правац своје будуће политике ка Кини, који је потом, према утврђеној расподели послова унутар двојца „Никсинџер”, Кисинџер требало да спроведе у практичну политику. 
Битно је напоменути да су се, иако су делили јединствену спољнополитичку визију, нарочито када је у питању однос према НР Кини, Никсон и Кисинџер руководили донекле различитом мотивацијом. Никсон је у нормализацији односа са Кином краткорочно видео прагматичан потез којим може приволети СССР да помогне окончању рата у Вијетнаму. Такође, био је уверен како је, на дуже стазе „окончање изолације 800 милиона Кинеза већ отклањало једну претњу миру" (Кисинџер, 1981, стр. 176). Кисинџерова мотивација је, пак, била нешто другачија - он је на уму имао холистичку геополитичку слику и био је фокусиран на далекосежне стратешке импликације америчког посезање за Кином. Наиме, он је веровао да ће Америка, уколико успе да развије и унапређује везе на оба дипломатска фронта - са СССР-ом и са Кином, креирати геополитички троугао у коме ће САД остварити стратешку предност и да ће јој управо та предност пружити више простора за осигуравање светског мира (Кисинџер, 1981, стр. 176). Кисинџер је имао на уму и то да би се евентуална совјетска инвазија на НР Кину сасвим извесно завршила поразом Пекинга, чиме би био нарушен геополитички еквилибријум. Такав сценарио подразумевао је губитак стратешке предности и знатно погоршање америчке позиције у хладноратовској арени. Из судара ове две донекле различите, али свакако комплементарне, мотивације родила се Никсонова политика триангулације чију суштину Кен Хјуз описује на следећи начин: „Политички, он [Никсон] се надао да ће покупити заслуге за смањивање хладноратовских тензија; геополитички, надао се да ће ојачати везе са Москвом и са Пекингом као предност која ће омогућити притисак на Северни Вијетнам да прекине рат или да га макар оконча нагодбом. Играо је на карту окретања Кине против СССР, СССР против Кине, и једних и других против Северног Вијетнама" (Hughes, 2021). Као илустративни пример ове вишедимензионе политике можемо навести следећу директиву коју је Никсон издао Кисинџеру непосредно по преузимању председничке функције. Наиме, Никсон је наложио свом саветнику да у контакту са источноевропским политичарима и дипломатама индиректно ствара утисак да нова америчка администрација разматра могућност приближавања НР Кини. Међутим, овај дипломатски маневар за свој стварни циљ није имао Пекинг, већ му је прави циљ био да испровоцира паљење „црвене лампице” у Москви, за коју се Никсон надао да ће, уколико прогута бачени мамац, постати кооперативнија по питању америчких интереса у Индокини. Инструментализујући могућност отпочињања америчко-кинеског дијалога (који још увек није био ни на помолу), Никсон се надао да ће навести СССР да и сам буде проактиван, те да ће се Кремљ, из жеље да предупреди и осујети зближавање Вашингтона и Пекинга, ажурније придружити 
америчким напорима да се рат у Вијетнаму оконча. Са друге стране, исти рецепт Никсон је употребио како би у Пекингу изазвао страх од америчко-совјетског зближавања. На својој првој председничкој конференцији за штампу, Никсон је недвосмислено означио НР Кину као непријатеља америчког народа, док је изјави датој неколико месеци касније експлицитно говорио о томе како САД и СССР имају заједнички интерес у обуздавању НР Кине (Кисинџер, 181, стр. 183). Тако је, шаљући контрадикторне сигнале обема странама, тандем „Никсинџер” започео процес увлачења међусобно завађених комунистичких титана у стратешки троугао билатералних односа (САД-СССР, САД-НР Кина, НР Кина-СССР) у коме би, иако су шансе за мултилатералну акцију биле немогуће, политика равнотеже снага представљала гарант мира између сва три актера (Кисинџер, 1981. стр. 191).

Иницијална идеја триангуларне дипломатије била је успостављање такве политичке климе у којој САД више неће бити главни непријатељ ни једној од две комунистичке силе, већ би међусобни фаталистички антагонизми били приземљени на ниво константног смењивања неповерења и сарадње. Појединачно гледано, када је СССР у питању, главни задатак триангулације био је да подстакне СССР на активније партнерство, не само по питању Вијетнама, већ и по питању детанта и преговора о неширењу нуклеарног наоружања. Са друге стране, када је реч о Кини, триангуларна дипломатија је требало да мотивише кинеско руководство да успостави билатералне односе са Вашингтоном, што би постепено водило смањењу кинеске (само)изолације и, напослетку, инклузији НР Кине у мећународну заједницу.

На „супротној” страни Пацифика Маоје такође имао своје стратешке калкулације. Не могавши да рачуна на могућност прављења ширег антисовјетског фронта унутар Источног блока, једина излазна карта која би Пекингу пружила могућност одвраћања СССР-а од агресије на њену територију било је придобијање подршке Запада. Мао је у овом спољнополитичком заокрету видео и нужност и неминовност, пре свега када је у питању обезбеђивање подршке САД - став који је сасвим извесно искристалисан након совјетске инвазије на Чехословачку. ${ }^{2}$ Но, америчка подршка никако није смела бити остварена по цену признања Тајвана,

У прилог овој тврдњи говори чињеница да је у новембру 1968, три месеца након инвазије на Чехословачку и непосредно након Никсонове победе на изборима, кинеска страна била та која је предложила наставак тзв. Варшавских преговора, и заказала сусрет америчких и кинеских дипломата за фебруар 1969. До овог сусрета ипак није дошло због дипломатског инцидента који је избио када је кинески отправник послова пребегао у Холандију и одатле тражио азил у Сједињеним Државама (Кисинџер, 1981, стр. 178, 181). 
тако да је кинеско комунистичко руководство са великим опрезом тумачило позитивне сигнале који су почели да стижу из Вашингтона убрзо након отпочињања Никсоновог првог мандата. Заправо, Никсон је могућност отварања ка Кини најавио, истина индиректно, већ у свом инаугурацијском говору када је парафразирао делове већ поменутог чланка из Foreign Affairs-a: „Нека сви народи знају да ће током трајања наше две администрације све линије комуникације бити отворене. Тражимо отворен свет - отворен за идеје, отворен за размену људи и роба - свет у коме нема људи великих и малих, који живе у љутој изолацији" (Кисинџер, 2020, стр. 202). Свакоме ко је био упознат са Никсоновим текстом из 1967. било је јасно на кога новоизабрани амерички председник алудира. Мао је разумео поруку послату између редова, те је зарад процене актуелне стратешке позиције Кине консултовао четири маршала Народно-ослободилачке армије - Чена Јиа (Chen Yi), Ниеа Ронгзена (Nie Rongzhen), Суа Сијанчијана (Xu Xiangqian) и Јеа Ђијангјинга (Ye Jianying). Они су испрва проценили да су САД и совјетски ревизионисти удружили снаге против НР Кине, али да су сукоби између Вашингтона и Москве ипак жешћи неко икада. Маршали су оценили да би САД у случају совјетско-кинеског сукоба остале по страни. Но, неколико месеци касније овај закључак је ревидиран, те је америчка пасивност одбачена као мало вероватна. У својој новој анализи кинески маршали су дали следећу процену: „Последња ствар коју би амерички империјалисти требало да допусте јесте да дође до победе совјетских марксиста у кинеско-совјетском рату, јер би тиме Совјети успели да изграде империју већу од америчке империје" (Кисинџер, 2020, стр. 203).Тиме се њихова процена поклопила се Маовим виђењем ситуације и тумачењем све интензивнијих, на први поглед контрадикторних, сигнала и мигова који су стизали из Вашингтона.

\section{МАНУЕТ (НЕ)ПРИЈАТЕЉСТВА}

Упркос подозрењу и опрезности кинеске стране, америчка триангуларна дипломатија је веома брзо дала прве резултате. Стрепећи од могућности интензивнијег америчко-совјетског зближавања (Кисинџер, 1981, стр. 181, 183), Пекинг је, након почетне суздржаности, веома обазриво, али ипак одлучно, прихватио амерички „позив на плес”. Манует две државе, како је, како смо већ рекли, Кисинџер окарактерисао њихово узајамно дипломатско поигравање, започет је низом једностраних америчких уступака и даље праћених топло-хладном политичком реториком. 
Кинеска страна је, са малом задршком, прихватила овакву игру преписујући истоветан образац понашања. Реторика обе земље остала је привидно непријатељска али су се иза њених кулиса почели ређати политички потези који се нису могли протумачити другачије него као гестови добре воље. Прво су се у несмањено ригидним изјавама које су долазиле са обе стране почели појављивати наговештаји спремности на попуштање. Наиме, на већ поменутој првој председничкој конференцији за штампу, Никсон је на следећи начин формулисао однос нове америчке администрације према НР Кини: „Док не дође до неких промена на њиховој страни не видим никаквих изгледа за промену наше политике" (Кисинџер, 1981, стр. 181). На први поглед, ова изјава је по својој садржини била крајње песимистична. Али, како Кисинџер примећује, она је такође имплицирала и то да би, уколико Кина промени свој образац понашања, Вашингтон последично променио свој однос према Пекингу. Пекинг је такође узвратио закулисном реториком. На Деветом конгресу Комунистичке партије Кине Маов заменик (и несуђени наследник) маршал Лин Бјао (Lin Biao) поднео је извештај у коме је наглашено како Кина нипошто не сме умањити своју револуционарну будност и потценити опасност од америчког империјализма или совјетског ревизионизма. У извештају је подвучено како Кина никога неће напасти, уколико сама не буде нападнута. Баш као и у случају Никсонових изјава, и овог пута су се испод узбуркане површине криле сублимиране поруке - Кина неће војно интервенисати у Вијетнаму, а Пекинг више не сматра САД за свог највећег непријатеља. Оваквом „нивелацијом” Вашингтона и Москве, који су сада у очима Пекинга постали једнака претња НР Кини, остварен је најважнији услов за успостављање триангуларне дипломатије - Кина више није сматрала САД за свог главног непријатеља (Кисинџер, 1981, стр. 189). Потом су уследили и конкретни међусобни уступци. На Никсонову и Кисинџерову иницијативу Стејт департмент је ублажио ембарго и рестрикције на трговину и путовања у НР Кину, при чему од Пекинга није захтеван реципроцитет. Кинези су, као одговор, ослободили два америчка држављана који су се, негде у исто време, јахтом насукала у близини Хонг Конга и чији је чамац за спасавање ушао у кинеске територијалне воде.

Како би убрзао развој догађаја Никсон је, за време своје председничке турнеје по свету, током посете азијским државама користио сваку прилику да индиректно пошаље поруку кинеском руководству да су САД спремне за успостављање формалних билатералних односа. Да би учинио да поруке добију на тежини, Никсон је начинио и нови конкретан уступак. Повукао је два америчка разарача која су патролирала водама Тајванског пролаза. Баш као и у случају смањења трговинских 
баријера, овај уступак није много коштао Америку. Права намена ових патрола била је више симболична него практична - стално присуство разарача подсећало је Пекинг на чињеницу да су САД спремне да војно бране Тајван од сваког напада који би дошао са кинеског копна. Стога је њихова замена другим војним бродовима, који су проређеним темпом наставили да плове истом морском рутом, била превасходно симболичног карактера. Ипак, и из овог поступка се, између редова, мада сад већ експлицитније, могао прочитати нови наговештај америчке спремности на релаксацију међусобних тензија. Пуштање на слободу још двоје америчких држављана (такође туриста који су залутали у кинеске воде) била је нова потврда да је кинеска страна прихватила овај неми дијалог. И тако су САД и НР Кина заплесале „замршени манует - тако пажљиво постављен да су обе стране увек могле тврдити да уопште нису у додиру, тако стилизиран да ниједна страна није морала преузети одговорност за почетак, толико елиптично заобилазан да постојећи односи на свакој страни нису долазили у опасност" (Кисинџер, 1981, стр. 201). Кисинџер наводи податак да су у периоду измећу новембра 1969. и фебруара 1970. америчке и кинеске дипломате широм света, приликом сусрета на разним дипломатским догађајима, почеле да комуницирају директно - чиме је направљен преседан од дугогодишње праксе међусобног избегавања" (Кисинџер, 1981, стр. 201; Кисинџер, 2020, стр. 211).

У децембру 1969. године уприличен је први сусрет посредством регуларних дипломатских представништва две државе. Наиме, амерички амбасадор у Варшави Валтер Стосел (Walter Stoessel) добио је позив да дође у званичну посету кинеској амбасади, где су два амбасадора разговарала о поновном покретању Варшавских преговора, а договорен је и њихов наредни састанак. Већ следећег дана Стејт департмент је изашао у јавност са саопштењем о овом сусрету и оценом да је исти протекао у „срдачној атмосфери" (Кисинџер, 1981, стр. 202). Сусрети америчких и кинеских дипломата у Варшави поново су заживели, али овог пута као знатно продуктивнији и сврсисходнији, усмерени ка побољшању односа дојучерашњих највећих непријатеља. Тако је амерички дијалог од „немог" постао изразито јасан и гласан. Преостало је само да се начини онај последњи корак - формални сусрет високих званичника две државе, ако не и онај на највишем нивоу - сусрет Никсона и Маоа. Да би се то догодило био је неопходан повод који би у светској јавности створио утисак спонтаности оваквог сусрета, чиме би, у складу са обострано прихваћеним правилима „мануета”, и Вашингтон и Пекинг избегли да буду окарактерисани као она страна која је попустила. Нажалост, нова дешавања у Индокини - овог пута у Камбоџи, убрзо ће довести до поновног заустављања америчко-кинеских разговора у Варшави. Догодило се то управо 
у тренутку када је америчка страна предлагала слање свог емисара у Пекинг или долазак кинеског представника у Вашингтон. Но, иако је амерички напад на северновијетнамске базе у Камбоџи испрва изазвао нове шумове у комуникацији Вашингтона и Пекинга (Кисинџер, 2011, стр. 654), он је такође додатно продубио раскол између СССР и НР Кине, што је изнова учврстило Маоа у уверењу да су односи са САД спољнополитички приоритет првог реда. Убрзо потом кинески лидер се и сам транспарентније укључио у напоре да се препреке наставку дијалога отклоне. Штавише, демонстрирао је сопствену одлучност да се исти коначно подигну и на виши ниво. У складу са кинеским маниром слања индиректних порука, он је на паради на Тјенанмену, одржаној поводом Националног дана НР Кине, у својој свечаној ложи угостио америчког писца Едгара Сноа (Edgar Snow), аутора чувене књиге „Црвена звезда над Кином" (Red star over China). Због свог афирмативног писања о кинеској револуцији, Сноу је био један од ретких западњака који је уживао поверење кинеског руководства. Изабравши Сноа за свог почасног госта на прослави највећег националног празника, Мао је у етар одаслао поруку да су односи са САД сада његова лична ствар и да је амерички изасланик добродошао у НР Кину. Преостало је само да се за тај сусрет обезбеди адекватан повод.

Прилику за то пружио је поменути сусрет репрезентативаца на Светском стонотениском првенству у Нагоји, чиме је америчко-кинески тихи „манует” прешао у своју завршну фазу, данас широм света познату као Пинг-понг дипломатија. Мотивисани гестом двојице спортиста, Кинези су позвали америчку репрезентацију у посету НР Кини. Након консултација са својом амбасадом у Токију, амерички спортисти су овај позив прихватили. Дочек који им је приређен могао би се окарактерисати као спектакуларан, а стонотенисере је, у Великој дворани народа, примио лично Чу Ен Лај, поручивши им како су отворили ново поглавље у односима два народа (Кисинџер б, 1981, стр. 739). Никсон и Кисинџер су на следећи начин протумачили гостољубивост кинеских домаћина: „На први поглед, позив младим Американцима симболисао је кинеску спремност на боље односе са САД; но, из дубљег слоја је произилазило - више од иједне дипломатске поруке преко било којег канала - да ће емисар који ће, очито, бити позван, ступити на пријатељско тло" (Кисинџер б, 1981, стр. 739). Неколико месеци касније, у јулу 1971. године, први амерички изасланик који ће посетити Пекинг биће нико други до Хенри Кисинџер, а његов сусрет са Чуом Ен Лајем поставиће темељ за историјску посету Никсона НР Кини у фебруару 1972 - догађај након којег хладноратовски свет више никада неће бити исти. 


\section{ЗАКљУЧАК}

Иако је светској јавности прича о Пинг-понг дипломатији „сервирана” као пример тријумфа спортског духа, добре воље и пријатељства над реалполитиком, она је испод вела појавности била управо супротно тријумф те исте реалполитике над хладноратовском идеолошком искључивошћу. Спорт, добра воља и личне симпатије које су се родиле између чланова америчке и кинеске стонотениске репрезентације играле су малу, готово безначајну улогу у зближавању САД и НР Кине. Сусрет у Нагоји и потоња посета америчких стонотенисера Пекингу били су тек повод, нипошто узрок заокрета у спољној политици две државе које су деценијама једна на другу гледале као на највећу претњу. Прави узрок америчко-кинеског rapprochement-а тицао се тада актуелних међународних околности, таман колико се тицао личне перцепције и стратешке визије кључних доносилаца политичких одлука на обе стране - Никсона и Кисинџера, са једне, и Маоа, са друге. Неоспорно је да је кључан подстицај заокрету у спољној политици две идеолошки и геополитички супротстављене државе дала управо хладноратовска међународна структура, која је навела и САД и Кину да теже првенствено заштити сопствене безбедности, задатак који је у доба нуклеарног одмеравања снага сасвим одговарао (нео)класичном виђењу основног императива сваке државе у међународној политици - обезбеђивање сопственог опстанка (Waltz, 1996, 54; Mearsheimer, 2014, pp. 45-47). Међутим „заслуге” за изналажење решења, којим је претња од међусобних сукоба унутар стратешког троугла САД-СССР-НР Кина умањена, чиме су на глобалној равни хладноратовске тензије релаксиране, припада првенствено поменутим индивидуалним актерима. Њихова процена међународне политичке ситуације и стратешка визија која је из ње изникла, упркос противљењу унутрашњих бирократских структура, учиниле су нормализацију односа између две државе могућом. Тиме су у одређеној мери релативизовале неореалистичку тезу о детерминишућем дејству мећународне структуре на државе као актере светске политике. Јер, у случају хладноратовског зближавања САД и НР Кине, не само да је стратешка визија која је водила лидере била у нескладу са „императивима” биполарне међународне структуре, већ је умногоме била супротна векторском дејству националних структура обе државе оличених у бирократском апарату навиклом на функционисање према устаљеним спољнополитичким шаблонима (на америчкој страни била је то брига да се не наруши утврђени дипломатски образац на релацији Вашингтон-Москва, на кинеској страни радило се о инсистирању да све спољнополитичке одлуке у обзир узимају тајванско питање). Па и више од тога, искорачивши из колотечине 
бинарне блоковске поделе и осмеливши се на рискантан покушај стратешке триангулације, двојац „Никсинџер” је отворио пут за будућу трансформацију међународног система од биполарног, преко униполарног ка триполарном, или чак мултиполарном поретку чије је конституисање у току. Без кинеског отварања свету, као директне последице Никсонове и Кисинџерове политике (као и Маовог разумевања и прихватања исте), ова промена не би била могућа - не би било кинеске економске реформе, кинеког економског чуда и „кимеричке” ${ }^{3}$ међузависности америчке и кинеске економије као главног обележја данашње међународне констелације снага. Напослетку, без поменутих догађаја не би било ни актуелне економске спољнополитичке офанзиве Пекинга оличене у Сијевој (Xi Jinping) иницијативи Појас и пут. Другим речима, све ово не би било могуће да наведени трио није заплесао дипломатски манует чији су смели кораци пркосили строго утврђеним правилима којима су се тада руководиле игре на међународном „плесном подијуму”.

\section{ЛИТЕРАТУРА}

1. Jackson, R., Sorensen, G. (2013). Introduction to International Relations: Theories and Approaches. Oxford: Oxford University Press.

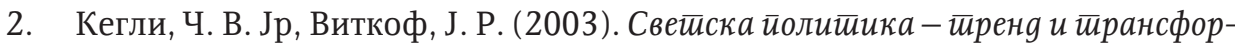
мација. Београд: Центар за студије Југоисточне Европе, Факултет политичких наука Универзитета у Београду, Дипломатска академија Министарства спољних послова Србије и Црне Горе.

3. Кисинџер, Х. (2020). О Кини. Београд: Клуб плус.

4. Кисинџер, Х. (2011). Дийломайија. Београд: Клуб плус.

5. Kisindžer, H. (1981). a. Memoari. Zagreb: Vjesnikova press agencija Mladost. Tom I.

6. Kisindžer, H. (1981), b. Memoari. Zagreb: Vjesnikova press agencija Mladost. Tom II.

7. Kobierecki, M. M. (2016). Ping-Pong Diplomacy and its Legacy in the American Foreign Policy. Polish Political Science Yearbook, 45, 304-316.

8. Mearsheimer, J. (2014). The Tragedy of Great Powers Politics. New York/London: W. W. Norton \& Company.

Неологизам који алудира на тренутну, готово симбиотску, економску међузависност НР Кине и САД. 
9. Moregentau, H. (1959). Politics among Nations: The Struggle for Power and Peace. New York: A. A. Knopf.

10. Nixon, R. M. (1967). Asia after Viet Nam. Foreign Affairs, 46 (1), 111-25.

11. Rose, G. (1988). Neoclassical Realism and Theories of Foreign Policy. World Politics, 51 (1), pp. 144-172.

12. Taliaferro, J. W. (2000). Security Seeking under Anarchy: Defensive Realism Revisited. International Security, 25 (3), 128-161.

13. Hudson, V. M. (2005). Foreign Policy Analysis: Actor-Specific Theory and the Ground of International Relations. Foreign Policy Analysis, 1, 1-30.

14. Wittkopf, E., R., Kegley, C. W. Jr. (2003). American Foreing Policy: Pattern and Process. Wadsforth: Thomson Learning.

15. Hughes, K. (2021). Richard Nixon. Charlottesville: Miller Center of Public Affairs, University of Virginia. https://millercenter.org/president/nixon (10.09.2021).

16. Waltz, K. N. (1996). International politics is not foreign policy. Security Studies, 6 (1), pp. 54-57.

\title{
Vladimir Ajzenhamer
}

\section{NIXON, KISSINGER, AND MAO: FROM STRATEGIC TRIANGULATION TO PING-PONG DIPLOMACY}

\begin{abstract}
This paper is intended to be an excursus on the topic of U.S.-China relations, which aims to familiarize the reader with the complex historical background of the diplomatic initiative known in the history of Cold War politics as 'ping-pong diplomacy'. It is one of the best known and most frequently cited examples of so-called sports diplomacy being employed to create opportunities to establish or resume bilateral relations between two countries - the Unites States of America and the People's Republic of China, whose mutual mistrust brought about by sharp ideological divides and competing geopolitical interests seemed impossible to overcome. This paper will use the example of Sino-American rapprochement to highlight the importance of political leadership in devising and implementing a foreign policy strategy. We will also use this example to demonstrate how the flexible positioning of the agent toward the structure can, in the long term, led to changes in the structure itself. The author primarily attributes the normalization of U.S.-China relations to the congruent strategic assessments by the Nixon-Kissinger political duo on the one hand and Chinese leader Mao Zedong on the other.
\end{abstract}


The first part of the paper describes the international circumstances that led to the Sino-American rapprochement, while the second part shifts the focus to the triangulation of bilateral relations between the U.S., the USSR, the U.S. and China, and China and the USSR.

Keywords:

Sino-American relations, Richard Nixon, Henry Kissinger, Mao Zedong, strategy, triangulation, U.S., China, USSR. 